the end of the cathode ray tube and projects the light forward past the tube towards the viewing screen. In order to correct for the spherical aberration introduced by a mirror of such large aperture, a corrector plate is introduced into the projection system. This plate has a non-spherical surface of complex shape and, in the Schmidt system, is mounted at the centre of curvature of the mirror. To produce such an optical system in glass is, however, a slow and expensive matter, since the aspherical surfaces of the corrector plate require long and patient hand-work by a highly skilled craftsman. Although many attempts have been made to produce such plates by means of machines designed to work the surfaces automatically, this has so far not been considered to be an economic proposition for the mass-production of domestic television receivers. These limitations have now been largely removed by recent developments in the formation and use of transparent plastic materials, and particularly by the introduction of a surface-finishing process by means of which plastic components of high optical quality can be produced on a large manufacturing scale.

A description of these developments with demonstrations of their application to television reception was given in a lecture on May 29 before the Television Society by Dr. D. Starkie, of the Plastics Division of Imperial Chemical Industries, Ltd. Two plastic materials are available in bulk supply in Great Britain. They are poly-methyl-methacrylate and poly-styrene, and are supplied in optically pure forms as 'Transpex 1' and 'Transpex 2 respectively, with transmission values for visible light corresponding approximately to those of crown and flint glass. These materials are sensibly unaffected by continuous exposure to sunlight, and, although they have a softening temperature of about $120^{\circ} \mathrm{C}$., by taking great care to avoid any strain in the material during fabrication, finished components show no measurable change in form when used under the most severe operating conditions. The production of the components takes place in two stages. First, a 'preform' is cast as accurately as possible by some known method. Then a thin skin of the same material is built up on the surface of this preform inside an optically worked glass mould, until the surface of the component makes optical contact at all points with the mould. A transparent mould material is necessary since part of the reproduction process is polymerization by light; but, in addition, glass is the hardest material available in bulk supply and all risk of scratching during use must be avoided. The aspheric moulds are first machined as accurately as possible and then finished by a skilled optical worker by hand. The preparation of such moulds is still a long and expensive matter; and it is only justified by the fact that, once a mould is made, a considerable number of accurate plastic reproductions can be made from it. The time required to make an optical component by the surface-finishing process is quite long, although the actual handling time by the operators is short. It has been decided, therefore, that in order to keep production costs low enough to allow the optical systems to be used in domestic television receivers, a large number of moulds should be used and these should travel through the various stages of the process on a mechanical conveyor. A factory to be operated along these lines is being prepared, and it is hoped to start manufacture at the end of this year.
Dr. Starkie demonstrated two prototype Schmidt television projection systems for home receivers, using cathode ray tubes of $2 \frac{1}{4}$ or $3 \frac{1}{2} \mathrm{in}$. diameter, respectively. The picture size given by both systems is 16 in. $\times 13$ in., the chromatic aberration is small, and the resolution is claimed to be far better than is required for the present B.B.C. television transmissions using 405-line scanning. Although the smaller of the two systems requires a 'throw distancê' of $40 \mathrm{in}$. between the cathode ray tube and the viewing screen, it was shown how this could conveniently be incorporated in a receiver console of normal dimensions. A third Schmidt system suitable for television projection in small cinemas was also demonstrated: this contained a mirror of 18 in. diameter and gave a picture with a length of diagonal of $12 \frac{1}{2} \mathrm{ft}$.

Although the lecture was primarily devoted to the use of plastic optical components in television reception, it was pointed out that since the new surface-finishing process allows complicated aspherical optical components to be made at a reasonable cost it is likely to have an important effect in the general field of applied optics.

\section{BRITISH IRON AND STEEL RESEARCH ASSOCIATION OPENING OF SKETTY HALL LABORATORIES}

$\mathrm{S}^{\mathrm{K}}$ ETTY HALL, Swansea, was opened on July 3 as the South Wales Laboratories of the British Iron and Steel Research Association. Mr. G. H. Latham, president of the British Iron and Steel Research Association, received a gold key from the Mayor of Swansea, and guests proceeded to an inspection of the Laboratories.

At present the bulk of the Association's work is of necessity carried out through the facilities of its members and at the universities and other appropriate institutions. Nevertheless, considerable progress has been made in establishing a number of laboratories specially adapted for co-operative research. For example, at the University of Sheffield a team is studying problems connected with rolling practice, and plans are well advanced for the establishment of a metal flow station in Sheffield for practical investigations into all forms of metal working and plastic de. formation problems ; in London, a physics laboratory is shortly to be opened ; there is a corrosion-testing laboratory at Birmingham, and marine biological work is carried out at Millport, Scotland.

At Sketty Hall, a mansion with an interesting local history extending over a century and a half, made available to the Association by the Swansea Corpora: tion, comprehensive facilities have been provided.

The chemistry section has a spacious laboratory, and the metallurgical section has two laboratories, all on the ground-floor. The metallurgical rooms ar respectively equipped with various heat-treatment furnaces and physical testing apparatus. On the same floor is the small workshop with the instrument mechanic's room adjacent, and the galvanizing and tinning shop, which will be sited in what seems to have formerly been a brew house. This shop is already furnished with ventilation for drawing off the brewery fumes, though the arrangements may have to be improved to dispose of the rather less appetizing byproducts of the shop's new functions. 
The first floor provides two laboratories for the physics section, and two for the electro-chemical section, in which there is equipment for plating. The physics section, being engaged on investigating the geometrical and physical characteristics of metal surfaces, is equipped with a sensitive profilometer of the latest pattern, and will have electron diffraction equipment later in the year. The profilometer is a Talysurf machine, on which a stylus traverses the specimen and records the roughness of the surface on a graph, with an adjustable magnification of 400-100,000 times. It also provides a rapid 'average' reading for the surface of the specimen.

It was found necessary to instal this equipment on a thoroughly stable base, and one of the physics laboratories has had to be provided with a ferroconcrete floor, on which the Talysurf and the electron diffraction apparatus are to be housed.

The second floor has comprehensive metallo. graphic facilities, with separate preparation laboratory and photographic room.

There are many problems which can be attempted within the scope of these facilities. Besides studies of metal surfaces, there are studies of the thickness and distribution of coatings of various sorts, and of the porosity of coatings. The Swansea team has already done considerable work on these subjects, which promises to be of ultimate benefit both to users and makers of the products concerned. Other problems which it will be the function of Sketty Hall to investigate include such questions as the influence of the composition of the steel and its method of manufacture on surface coatings; the physical and chemical characteristics of metal surfaces; the adhesion of coatings ; electroplating ; de-wetting and many others.

Other work carried out at Sketty Hall involves field tests on melting furnaces and works in the South Wales area, concerned with such matters as fuel distribution and gas flow in gas producers (in conjunction with the British Coal Utilization Research Association); the effect of deterioration of ingot mould surfaces on the surface of the ingot and subsequent products; the determination of the moisture content of hot raw producer gas, and the assessment of the value of instrumentation of openhearth furnaces. For these purposes a quick immersion thermocouple is being used, and apparatus has been developed for rapid determination of the moisture in producer gases. These, together with other equipment, are being mounted in a mobile laboratory.

The organisation of the Swansea laboratories is the task of the Coatings Committee of the Mechanical Working Division of the Association, one of the six divisions under which the Association's work is organised. This Committee was formed about fourteen months ago, and the first meeting was held on May 15, 1946, under the chairmanship of Capt. $H$. Leighton-Davies, who remains the chairman to-day. The terms of reference of this Committee, for which the greater portion of the work of Sketty Hall is to be carried out, are: "To consider and investigate all matters concerning metallic and other inorganic coatings on steel and all processes for surface preparation associated therewith". 'This is, of course, a very wide field, involving close collaboration between research workers in allied fields (such as the co-operation that exists between the British Non-Ferrous Metals Research Association and the British Iron and Steel Research Association) and between research workers and users.
The formation of the Coatings Committee was not by any means the origin of co-operative research in South Wales, which was started in 1932 by the South Wales Siemens Steel Association and the Welsh Sheet and Plate Manufacturers' Associations. A team of investigators then worked at University College, Swansea, under Mr. D. Luther Phillips.

Early in 1946 arrangements were made for the British Iron and Steel Research Association to take over the work of the two research Committees, and it is the new function of Sketty Hall to house the continuation and expansion of their investigations. Mr. Luther Phillips is now in sole charge of the laboratories, and the closeness of Sketty Hall to University College, Swansea, ensures continuity.

A lunch at Swansea Civic Centre followed the opening ceremony. Besides Mr. G. H. Latham and the Mayor of Swansea, Mr. Percy Morris, M.P., Sir Lewis Jones (vice-president of University College, Swansea), Capt. H. Leighton-Davies and Sir Charles Goodeve (director of the Association) spoke.

Mr. Latham emphasized the part co-operative research has to play in ensuring that we have the steel output as necessary to Great Britain's economic recovery as the output of coal. Throughout all the speeches there was much emphasis on the healthy degree of co-operation which exists between the Research Association, the University College, the municipality and local industry. In inviting industrialists to make the freest possible use of Sketty Hall's facilities, Sir Charles Goodeve stressed the fact that science alone is not a panacea for our ills, but must be allied to strong and continuous effort. Tribute was paid to the very considerable amount of work that had gone into the conversion of Sketty Hall. Its rapid progress must be laid to the credit of Mr. Luther Phillips and his staff, and to the efforts of the contractors.

\section{FORTHCOMING EVENTS}

(Meeting marked with an asterisk * is open to the public)

$$
\text { Monday, July } 21
$$

ANGLO-AdSTRIAN Society (at Gas Industries House, 1 Grosvenor Place, London, S.W.1), at 8 p.m.- Prof. H. Mark (Institute of Polymer Research, Brooklyn): "Austrian Science, Past and Future".

$$
\text { Saturday, July } 26
$$

A yatedr Entomologists' Societr (at Buckingham Gate Central Schoof Wilfred Street, London, S.W.1), at 2 p.m.-Annual Exhibition.*

\section{APPOINTMENTS VACANT}

Applications are invited for the following appointments on or before the dates mentioned:

LECTURER IN PHYSICS (honours graduate, to teach physics to B.Sc. tandard) at the Municipal Technical College and School of ArtThe Director of Education, Education Office, Library Street, Black-

burn (July 26 ). University, Aberdeen (July 26)

LECTURER IN ZOOLOGY AND CHEMISTRY-The Registrar, Merchant enturers' Technical College, Bristol (July 26).

The Principal, Dudley LECTURER IN Mire Technical College, Dudley (July 26)

and Staffordshire Technical College, Dudley (July 26) Naval College, LECTURER IN APPLIED MECHANICS at the Royal Naval College, Greenwich-The

Cistrar, CHIF LECTURER TN MECANA Comerce, Leicester (July 26). Leicester College of Technology and Commerce, Leicester (July 26). LEOTURER IN GEOGRAPHY at the Liverpool College of CommerceThe Director of Education, 14 Sir Thomas Street, Liverpool 1 (July 26) LECTURER IN CHEMISTRY AND MATHEMATICS at the Oxford School of Technology-The Chief Education

77 George Street, Oxford (July 26). ham Gas Company, 95 High Street, Rochester (July 29). 